\title{
Environmental and occupational respiratory diseases - 1051. Intractable sneezing - case report
}

\author{
Vattikonda Sathavahana Chowdary \\ From 2nd WAO International Scientific Conference (WISC 2012) \\ Hyderabad, India. 6-9 December 2012
}

\section{Background}

Intractable Sneezing (IS) is a relatively uncommon disorder. It has been reported in about 45 cases in literature. We report one such case and how it was managed is described.

\section{Methods}

An 11 year old female child was referred to the Allergy clinic in the Otolaryngology department with recurrent spells of sneezing of about $2 \frac{1}{2}$ months duration. Each spell consisted of more than 200 sneezes in 25 minutes. The child underwent clinical evaluation by primary care physician and ENT specialist. There was no relief of symptoms with the standard treatment.A thorough clinical and psychosocial history was taken from the child and the parents. Clinical examination and relevant investigations to exclude any organic causes for sneezing were done. Child's psychological assessment was done by the clinical psychologist.

\section{Results}

A final diagnosis of psychogenic Intractable Sneezing (PIS) was made.The psychological history revealed the evidence related to psychological stress. She was not able to cope up with her peer group in the school with respect to academic pressures and expectations because of learning disabilities.A result of the above situation was anxiety. So she was using intractable sneezing as a defense to cope up with stress, so that she could abstain from going to school. The child underwent behavioral and psychotherapy and the parents underwent counseling. There was a complete resolution of symptoms in a period of 4 weeks.

Head \& Neck Surgery, Allergy Clinic., Apollo Hospitals, Jubilee Hills,

\footnotetext{
Hyderabad, India., Hyderabad, India
}

(c) 2013 Chowdary; licensee BioMed Central Ltd. This is an Open Access article distributed under the terms of the Creative Commons

\section{Conclusions}

A review of the literature suggests that 38 out of 45 reported cases of intractable sneezing (i.e. nearly $85 \%$ ) are supposed to be psychogenic in origin. PIS is supposed to be a manifestation of conversion disorder. It is typically seen in children and adolescents and is more common in females. The treatment is basically, psychotherapy with or without anxiolytic medication. PIS is an unusual disorder, but a timely diagnosis of this condition can avoid unnecessary medical trials, parental anxiety and poor school performance as most of the cases are very young.

Published: 23 April 2013

\section{doi:10.1186/1939-4551-6-S1-P50}

Cite this article as: Chowdary: Environmental and occupational

respiratory diseases - 1051. Intractable sneezing - case report. World Allergy Organization Journal 2013 6(Suppl 1):P50.

Submit your next manuscript to BioMed Central and take full advantage of:

- Convenient online submission

- Thorough peer review

- No space constraints or color figure charges

- Immediate publication on acceptance

- Inclusion in PubMed, CAS, Scopus and Google Scholar

- Research which is freely available for redistribution \\ () Biomed Central}

